(2) Open Access Full Text Article

ORIGINAL RESEARCH

\title{
Lentinus squarrosulus (Mont.) mycelium enhanced antioxidant status in rat model
}

This article was published in the following Dove Press journal:

Drug Design, Development and Therapy

6 November 2015

Number of times this article has been viewed

\author{
Nor Adila Mhd Omar ${ }^{1,2}$ \\ Sumaiyah Abdullah ${ }^{1,3}$ \\ Noorlidah Abdullah' \\ Umah Rani Kuppusamy ${ }^{1,4}$ \\ Mahmood Ameen Abdulla ${ }^{1,4}$ \\ Vikineswary Sabaratnam' \\ 'Mushroom Research Centre, Institute \\ of Biological Sciences, Faculty of \\ Science, University of Malaya, Kuala \\ Lumpur, Malaysia; ${ }^{2}$ Faculty of Industrial \\ Sciences and Technology, Universiti \\ Malaysia Pahang, Gambang, Kuantan, \\ Pahang, Malaysia; ${ }^{3}$ Department of Plant \\ Protection, Faculty of Agriculture, \\ Universiti Putra Malaysia, Serdang, \\ Selangor, Malaysia; ${ }^{4}$ Department \\ of Biomedical Science, Faculty of \\ Medicine, University of Malaya, Kuala \\ Lumpur, Malaysia
}

\begin{abstract}
Aim: Lentinus squarrosulus is an edible wild mushroom commonly found in Asia. This species has several interesting features such as rapid mycelial growth, and hence has the potential to be used as food, functional food, and nutraceuticals. Our previous study shows that L. squarrosulus contains potent antioxidant compounds in vitro. This study aims to investigate the in vivo bioavailability of $L$. squarrosulus mycelium extract and its antioxidant effect on biomarkers of antioxidant defense and oxidative stress.
\end{abstract}

Methods: Water extract of mycelial biomass of L. squarrosulus was analyzed for in vivo antioxidant effects, including cupric-reducing antioxidant capacity (CUPRAC), glutathione peroxidase (GPx), xanthine oxidase (XO), advanced oxidation protein products (AOPPs), and lipid hydroperoxides (LHPs) at 0 and 28 days. GPx and XO were also analyzed in liver homogenates. Normal Sprague Dawley rats were treated with 250 and $500 \mathrm{mg} / \mathrm{kg}$ of extract for 28 days.

Results: The serum CUPRAC level increased after treatment with both concentrations, indicating that there was sufficient bioavailability of the extract which contributed to the total antioxidant capacity. GPx activity in both serum and liver was increased and this correlated with LHP level after treatment with $250 \mathrm{mg} / \mathrm{kg}$ of extract, but XO activity was significantly decreased after treatment with $500 \mathrm{mg} / \mathrm{kg}$ of the extract. Lack of difference between AOPP levels implied that there were no significant changes in oxidative damage of protein after treatment.

Conclusion: This study clearly showed that L. squarrosulus mycelium antioxidant extract contains absorbable antioxidants that enter the circulating plasma and cause a significant acute increase in plasma antioxidant capacity. Thus, the water extract of L. squarrosulus mycelium, which can be obtained abundantly by liquid fermentation, may serve as an antioxidant ingredient in functional foods and nutraceuticals.

Keywords: mushroom, mycelia, CUPRAC, GPx, AOPP, xanthine oxidase

\section{Introduction}

Free radicals possess unpaired electrons and are thus defined as molecules or atoms with one or more unpaired electrons. Free radicals are usually unstable and highly reactive. To protect from these highly reactive intermediates, living organisms possess a defense system consisting of both enzymatic and nonenzymatic antioxidants that scavenge them. Nevertheless, under several situations, the rate of generation of reactive oxygen species (ROS) exceeds that of their removal, thus oxidative stress occurs. ${ }^{1}$ Conditions that bring about oxidative stress caused damage to lipids, proteins, enzymes, carbohydrates, and deoxyribonucleic acid (DNA) in cells and tissues. It has also been known to be associated with pathogenesis of various disorders such as cancer, diabetes, and other age-related diseases. ${ }^{2}$

Antioxidants produced internally by the body or externally derived from the diet are compounds that can prevent or slow the oxidative damage to our body and play important roles as prophylactic and therapeutic agents in many diseases. ${ }^{3}$ Antioxidants
Correspondence: Noorlidah Abdullah Mushroom Research Centre, Institute of Biological Sciences, Faculty of Science, University of Malaya, 50603

Kuala Lumpur, Malaysia

Tel +60379674371

Fax +60379674178

Email noorlidah@um.edu.my (c) (i) (5) 2015 Mhd Omar et al. This work is published by Dove Medical Press Limited, and licensed under Creative Commons Attribution - Non Commercial (unported, v3.0) BY LC License. The full terms of the License are available at http://creativecommons.org/licenses/by-nc/3.0/. Non-commercial uses of the work are permitted without any further hew to how to request permission may be found at: http://www.dovepress.com/permissions.php 
act as "free radical scavengers" and hence prevent and repair damage done by these free radicals. Free radical formation is associated with the normal natural metabolism of aerobic cells.

The antioxidant defense system in the body works at a molecular level to protect the cell membrane, lipoproteins, and DNA from the damaging effects of free oxygen radicals. ${ }^{4}$ Endogenous antioxidants are enzymes that are primarily physiologic in origin; exogenous antioxidants include nutrients and nonnutrients that enter the body through the diet. As a defense mechanism against the toxic ROS, cells are provided with nonenzymatic and enzymatic antioxidants; the former include glutathione (GSH), vitamin E, ascorbic acid, $\beta$-carotene, and uric acid. Enzymes involved in antioxidant defenses include superoxide dismutase, catalase (CAT), selenium-dependent glutathione peroxidase (SeGPx), selenium-independent glutathione peroxidase (GPx), alkyl hydroperoxide reductase, glutathione S-transferase, and glutathione reductase. ${ }^{5}$

Mushrooms have been used as food for centuries and recently have gained popularity as functional foods and as a source of physiological beneficial medicine. Mushrooms accumulate a variety of secondary metabolites, including phenolic compounds, polyketides, terpenes, and steroids. ${ }^{6}$ Studies by Wong et $\mathrm{al}^{7}$ and Kho et $\mathrm{al}^{8}$ showed that the ferric-reducing antioxidant power of Hericium erinaceus and Auricularia auricula-judae mycelia extracts showed good positive correlation with the total phenolic content. Phenolic antioxidants are potent free radical scavengers because they can donate their alcoholic hydrogen atom to free radicals. The antioxidants present in mushrooms are of great interest as protective agents to help the human body, reducing oxidative damage without any interference. ${ }^{9}$

Lentinus squarrosulus is an edible mushroom commonly found in the wild in Malaysia and has not yet been cultivated on a large scale. It is a white rot saprophytic fungus, which lives on dead or decayed wood in forest. Mushroom mycelia have been reported to be a good source of antioxidants. ${ }^{10}$ The mycelium of L. squarrosulus contains high protein $(57.6 \%)$ and low total fat $(0.5 \%)$ and is also rich in magnesium $(0.4 \%)$, potassium $(3.8 \%)$, and vitamin $\mathrm{B}_{3}(0.2 \%) .{ }^{11}$ It can be cultivated by liquid fermentation to produce mycelial biomass. Moreover, it is a fast and reliable method for the production of uniform mycelial biomass. Our previous work has shown that L. squarrosulus mycelial extract has good antioxidant properties in vitro and it has no toxic effects, even at high doses. ${ }^{11}$ It is unknown whether the antioxidants can be absorbed and utilized in vivo to lower the risk of chronic diseases. Hence, the aim of this study was to evaluate the bioavailability of L. squarrosulus antioxidant extract in vivo by determining the effect on biomarkers of antioxidant defense and oxidative stress.

\section{Materials and methods Mushroom samples}

Pure culture of L. squarrosulus (KUM50016) was prepared from fresh basidiocarp collected from various forests in Peninsular Malaysia. The basidiocarp of L. squarrosulus specimen collected was described and then dried as herbarium specimens. Both dried specimens and pure culture were deposited in Mushroom Research Centre, University of Malaya, Kuala Lumpur, Malaysia.

\section{Preparation of $L$. squarrosulus antioxidant extract}

Mycelium of L. squarrosulus was cultured in $500 \mathrm{~mL}$ Erlenmeyer flasks containing glucose (1.5\%), yeast extract $(0.8 \%)$, malt extract $(0.8 \%)$, and peptone $(0.8 \%)$ liquid medium under static condition at $25^{\circ} \mathrm{C}$. After 2 weeks, mycelia broth was harvested and homogenized in water at a ratio of $1: 1$. The broth was boiled for 30 minutes and centrifuged at $3,000 \times g$ for 15 minutes. The supernatant was then filtered using Whatman ${ }^{\circledR}$ Grade No 1 filter paper and the water extract was freeze-dried.

\section{Animals}

Adult Sprague Dawley rats aged 6-8 weeks and weighing between 180 and $200 \mathrm{~g}$ were purchased from Animal House Science Centre, Faculty of Medicine, University of Malaya, Kuala Lumpur, Malaysia. The animals were housed at $27^{\circ} \mathrm{C} \pm 2^{\circ} \mathrm{C}$ temperature and fed with standard laboratory pellet and provided water ad libitum. Experimental protocols were approved by the ethical committee (which follows the guidelines of Animal Care and Use Committee), Laboratory of Animal Science Centre, Faculty of Medicine, University of Malaya (Ethics no: ISB/11/02/2009/NAO(R)).

\section{Assessment of in vivo antioxidant effects of $L$. squarrosulus extract}

A total of 18 male Sprague Dawley rats aged 6-8 weeks were used. The animals were divided randomly into three groups of six animals each namely control group, high-dose and low-dose groups. Control group was given plain drinking water, whereas treated groups were fed with $L$. squarrosulus extracts at two different doses of $250 \mathrm{mg} / \mathrm{kg}$ (low-dose group) and $500 \mathrm{mg} /$ $\mathrm{kg}$ (high-dose group) per day for 28 days. The animals were 
maintained according to standard guidelines. Food was given ad libitum. Blood was collected into commercial blood collection tubes (Greiner VACUETTE ${ }^{\circledR} Z$ serum Sep Clot Activator, Greiner Bio-One $\mathrm{GmbH}$, Germany) at day 0 and day 28 for analysis. For each sample, serum was separated from blood by centrifugation at $3,500 \times g$ for 10 minutes within 2 hours of blood collection and stored at $-80^{\circ} \mathrm{C}$ for analysis. The serum was used to analyze the antioxidant biomarkers using cupricreducing antioxidant capacity (CUPRAC), glutathione peroxidase (GPx), xanthine oxidase (XO), advanced oxidation protein products (AOPPs), and lipid hydroperoxide (LHP) levels. After 28 days, the rats were sacrificed and the liver samples were excised from the carcass and homogenized using a homogenizer (Ingenieurburo CAT, M. Zipperer GmbH, ShaftT17N, Staufen im Breisgau, Germany) at ratio of 1:10 of liver to ice-cold phosphate buffer solution (PBS). The homogenates were centrifuged at $3,500 \times g$ for 10 minutes. The resulting supernatants were stored at $-80^{\circ} \mathrm{C}$ for the assessment of GPx and XO.

\section{Analysis of antioxidant activities CUPRAC assay}

CUPRAC of $10 \mu \mathrm{L}$ serum was measured according to the method of Apak et $\mathrm{al}^{12}$ based on the principle of utilizing copper (II)-neocuproine reagent as the chromogenic oxidizing agent. The mixture of $1 \mathrm{~mL}$ of copper (II) $\left(1.0 \times 10^{-2} \mathrm{M}\right)$, neocuproine $\left(7.5 \times 10^{-3} \mathrm{M}\right)$, ammonium acetate buffer solution ( $1 \mathrm{M} ; \mathrm{pH} 7$ ), and $\mathrm{dH}_{2} \mathrm{O}$ were added to make a final volume of $4.1 \mathrm{~mL}$. After 30 minutes incubation, the absorbance at $450 \mathrm{~nm}$ was measured against a reagent blank. The results of antioxidant activity were expressed as absorbance at $450 \mathrm{~nm}$ and compared with ascorbic acid as a positive control.

\section{GPx activity}

All the enzymatic assays were carried out at $25^{\circ} \mathrm{C}$ using a microplate scanning spectrophotometer and run in triplicate in 96-well microplates. GPx activity was measured by using Glutathione Peroxidase Assay Kit (Cayman Chemical Company, Michigan, USA). The assay was based on glutathione reductase-coupled oxidation of NADPH using hydrogen peroxide as the substrate. One unit of GPx enzyme activity was defined as micromoles of NADPH oxidized per minute per milligram protein.

\section{Xanthine oxidase activity}

Serum and liver XO activity was determined according to the modified method of Singh et al. ${ }^{13}$ One milliliter of substrate buffer was added with $5 \mu \mathrm{L}$ of $100 \mathrm{mg} / \mathrm{mL}$ uricase and $50 \mu \mathrm{L}$ sample before incubating at $37^{\circ} \mathrm{C}$ for 10 minutes. Reagent solution consisting of $2 \mathrm{mM}$ ABTS and 5,000 U/L peroxidase dissolved in $50 \mathrm{~mL} 66.7 \mathrm{mM}$ phosphate buffer (pH7.9) was mixed well before adding $1 \mathrm{~mL}$ of $2 \mathrm{M}$ perchloric acid $\left(\mathrm{HClO}_{4}\right)$. The mixture was centrifuged at $3,500 \times g$ for 5 minutes. The absorbance of the supernatant was read at $410 \mathrm{~nm}$ and the results were expressed as micromoles per milligram proteins.

\section{AOPP assay}

AOPP was determined by the method of Witko-Sarsat et al. ${ }^{14}$ The premixed reagent containing $81 \%(\mathrm{w} / \mathrm{v})$ PBS solution, $15 \%(\mathrm{v} / \mathrm{v})$ of $50 \%$ acetic acid, and $4 \%(\mathrm{w} / \mathrm{v})$ potassium iodide was prepared. This reagent $(200 \mu \mathrm{L})$ was added into each of the microtiter plate wells that contained $18 \mu \mathrm{L}$ of the serum samples using eight-channel pipettes. The absorbance of the reaction mixture was immediately read at $340 \mathrm{~nm}$ against a blank (water). A series of standards were prepared by adding the premixed reagent to $18 \mu \mathrm{L}$ of chloramine-T solution $(0-500 \mu \mathrm{mol} / \mathrm{L})$. The chloramine-T absorbance at $340 \mathrm{~nm}$ was linear within the range of $0-500 \mu \mathrm{mol} / \mathrm{L}$. The AOPP concentrations were calculated from the standard curve and were expressed as micromoles per liter of chloramine-T equivalents.

\section{LHP assay}

LHP was measured according to the modified method of Esterbauer and Cheeseman. ${ }^{15}$ Serum $(150 \mu \mathrm{L})$ was added to 375 $\mu \mathrm{L}$ 1-methyl-2-phenylindole in acetonitrile and $225 \mu \mathrm{L} \mathrm{HCl}$ $(5 \mathrm{M})$ in a microcentrifuge tube and incubated in a water bath at $45^{\circ} \mathrm{C}$ for 40 minutes. After centrifugation at $19,600 \times g$ for 5 minutes, the reaction mixture was read at $586 \mathrm{~nm}$. 1,1,3,3Tetraethoxypropane was used as a standard at concentrations of $0,2.5,5,10,15$, and $20 \mu \mathrm{M}$. The LHP concentrations were calculated from the standard curve and were expressed as micromoles per liter of tetraethoxypropane equivalents.

\section{Statistical analysis}

The results were expressed as mean \pm standard error of the mean (SEM), analyzed by SPSS 17.0 (Window 2003; SPSS Inc., Chicago, IL, USA). Differences between groups were tested by one-way analysis of variance. $P$-values less than 0.05 were considered statistically significant. All in vivo antioxidant assays were performed in six replicates.

\section{Results}

The CUPRAC level in serum after treatment for 28 days with L. squarrosulus mycelium extract in rats with two concentrations, 250 and $500 \mathrm{mg} / \mathrm{kg}$, is shown in Figure 1. 


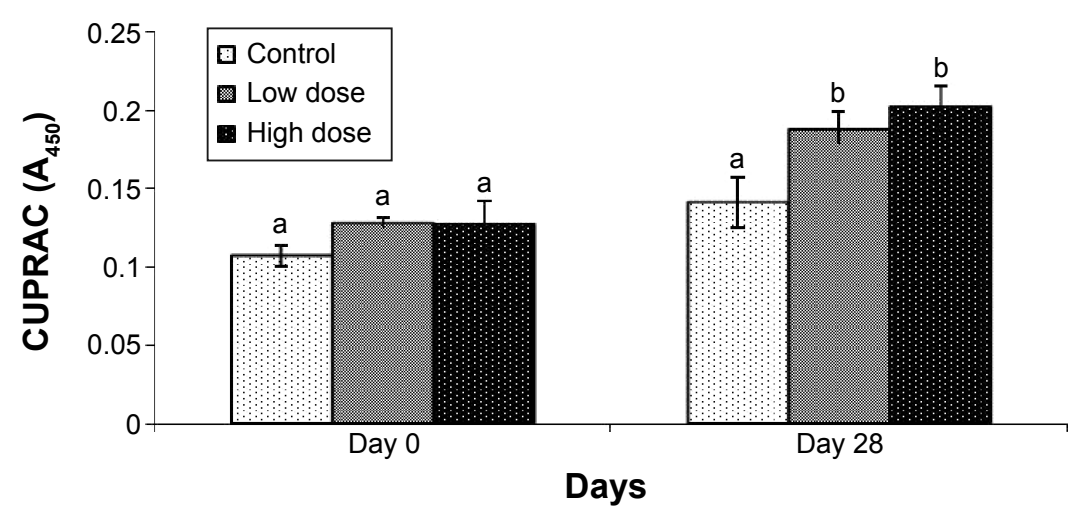

Figure I CUPRAC levels in serum at 0 and 28 days of treatment under nonoxidative stress condition.

Notes: Mean values with different letters were significantly different $(P<0.05)$ between the control and treated groups. Values expressed are mean \pm SEM of six animals. Low dose $=250 \mathrm{mg} / \mathrm{mL}$ and high dose $=500 \mathrm{mg} / \mathrm{mL}$.

Abbreviations: CUPRAC, cupric-reducing antioxidant capacity; SEM, standard error of mean.

Both doses enhanced serum CUPRAC significantly compared to the untreated sample; however, there was no significant difference between low and high doses. Result shows that the cupric-reducing capacity of the L. squarrosulus extracts increased along with the increased concentration (Figure 1). GPx activity in serum and liver homogenate is shown in Figure 2. GPx was significantly enhanced in the low-dose treated extract compared to untreated and high dose. The GPx activity in serum between animals treated with both doses of $L$. squarrosulus extract was nonsignificantly different when compared to the control group at day 0. However, GPx activity in serum at low dose was significantly higher compared to the control and high-dose groups after 28 days of treatment. Meanwhile, the GPx activity in liver homogenate at both doses was significantly higher compared to control group after 28 days of treatment (Figure 2). Figure 3 shows that $\mathrm{XO}$ activity in both serum and liver was significantly decreased compared to the control group. However, in the control group and in the group treated with low dose of extract, the XO level was significantly increased. The level of AOPP in the rats of control group and the rats treated with $L$. squarrosulus at 0 and 28 days is shown in Figure 4. The AOPP level between normal rats and rats treated with the $L$. squarrosulus extract at day 0 was nonsignificant. However, after a treatment period of 28 days with $L$. squarrosulus mycelial extract, the rats treated with high dose showed nonsignificant reduction in AOPP level compared to the control group. The AOPP level in the control group was higher after 28 days compared to day 0 . This study showed no significant difference in LHP levels between normal rats and rats treated with the $L$. squarrosulus extract at day 0 (Figure 5). However, after a period of 28 days, the LHP levels were significantly increased in serum of rats after treatment with low-dose L. squarrosulus extract, compared with the control group.

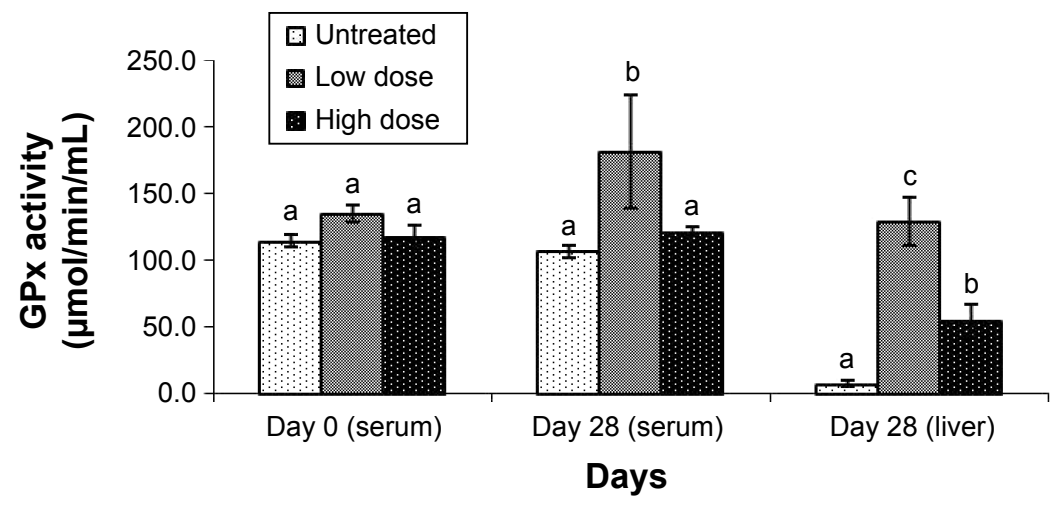

Figure 2 GPx activity in serum at 0 and 28 days and in liver at 28 days of treatment under nonoxidative stress condition.

Notes: Mean values with different letters were significantly different $(P<0.05)$ between the control and treated groups. Values expressed are mean \pm SEM of six animals. Low dose $=250 \mathrm{mg} / \mathrm{mL}$ and high dose $=500 \mathrm{mg} / \mathrm{mL}$.

Abbreviations: GPx, glutathione peroxidase; SEM, standard error of mean. 


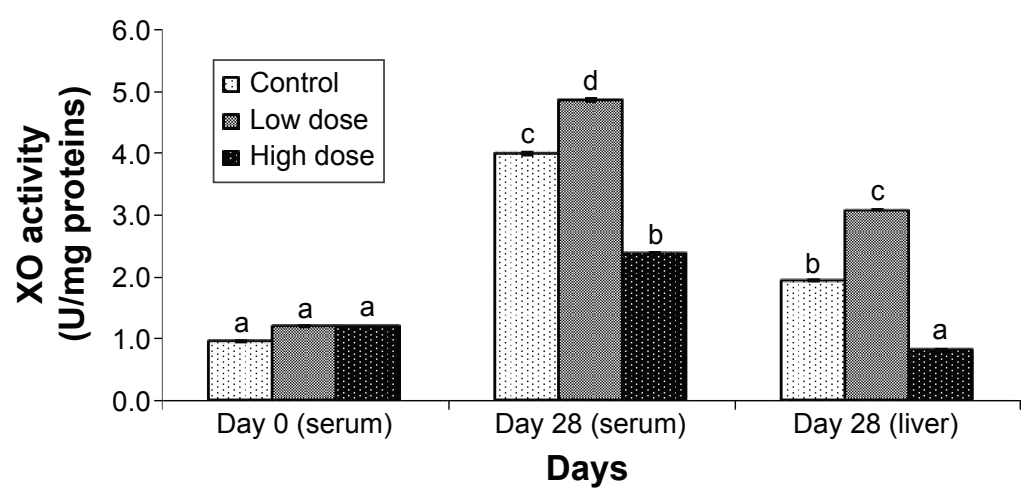

Figure $3 \times O$ levels in serum at 0 and 28 days and in liver at 28 days, under nonoxidative stress condition in rats.

Notes: Mean values with different letters were significantly different $(P<0.05)$ between the control and treated groups at 0 and 28 days of treatment. Values expressed are mean \pm SEM of six animal replicates. Low dose $=250 \mathrm{mg} / \mathrm{mL}$ and high dose $=500 \mathrm{mg} / \mathrm{mL}$.

Abbreviations: $\mathrm{XO}$, xanthine oxidase; SEM, standard error of mean.

\section{Discussion}

It is well known that every product that is active in vitro may or may not be active in vivo depending upon its bioavailability. If antioxidants are absorbed and enter the systemic circulation, an increase in the serum antioxidant capacity will occur. The magnitude of the increase is reflected in the amounts of antioxidants absorbed. In this study, the CUPRAC assay was used to monitor absorption, and Figure 1 shows that CUPRAC level in serum was significantly elevated in the groups treated with $L$. squarrosulus extract after a period of 28 days. The results showed that the extract caused an increase in the total antioxidant capacity in serum in a dose-dependent manner. Porkkala-Sarataho et $\mathrm{al}^{16}$ reported that long-term administration (between 12 and 36 months) of vitamins $\mathrm{C}$ and $\mathrm{E}$ alone or in combination at respective daily dosages of 500 and $182 \mathrm{mg}$ was not able to modify the antioxidant capacity of plasma measured using total peroxyl radical trapping. Although the test product was rich in phenolic compounds, mainly anthocyanins, and showed a high antioxidant activity, no significant effect was observed on the antioxidant status or on any biomarkers of oxidative stress (lipid and DNA damage). This L. squarrosulus antioxidant extract has high phenolic content of $39.16 \mathrm{mg} / 100 \mathrm{~g}$ and 1,1-diphenyl-2-picrylhydrazyl radical scavenging activity at a half-maximal inhibitory concentration of $14.29 \mathrm{mg} / \mathrm{mL} .{ }^{10}$ Hatano et a ${ }^{17}$ reported that phenolic compounds are very important constituents and that their radical scavenging ability is due to their hydroxyl groups. The phenolic compounds may contribute directly to the oxidative action. ${ }^{18}$

GPx is an enzyme which catalyzes the destruction of peroxides, including hydrogen peroxide, by the oxidation of reduced glutathione. The enzyme is present in mammalian red blood cells and it protects hemoglobin against oxidative breakdown by hydrogen peroxide. It is well established that the enzymes such as CAT and GPx play an important role in protecting red blood cells from the effects of oxidizing agents. ${ }^{19}$ GPx activity in serum and liver homogenate is

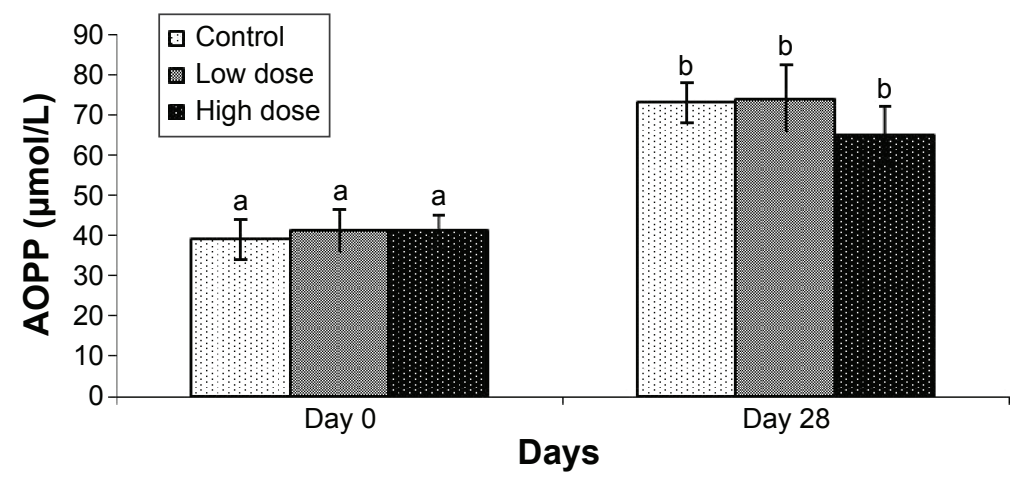

Figure 4 AOPP levels in rats before and after treatment with Lentinus squarrosulus under nonoxidative stress condition.

Notes: Mean values with different letters were significantly different $(P<0.05)$ between the control and treated groups. Values expressed are mean \pm SEM of six animals. Low dose $=250 \mathrm{mg} / \mathrm{mL}$ and high dose $=500 \mathrm{mg} / \mathrm{mL}$.

Abbreviations: AOPP, advanced oxidation protein product; SEM, standard error of mean. 


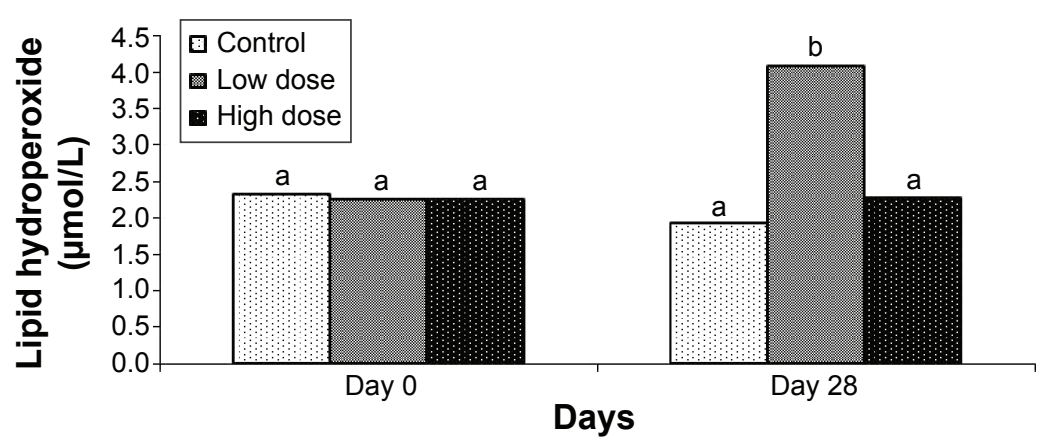

Figure 5 LHP levels in serum at 0 and 28 days of treatment under nonoxidative stress condition.

Notes: Mean values with different letters were significantly different $(P<0.05)$ between the control and treated groups. Values expressed are mean \pm SEM of six animal replicates. Low dose $=250 \mathrm{mg} / \mathrm{mL}$ and high dose $=500 \mathrm{mg} / \mathrm{mL}$.

Abbreviations: LHP, lipid hydroperoxide; SEM, standard error of mean.

depicted in Figure 2. No significant difference in GPx activity was observed in serum between animals treated with high dose of $L$. squarrosulus extract as opposed to low dose when compared to the control group. However, GPx activity in liver homogenate at both doses was significantly higher compared to control group after 28 days of treatment. This correlated with the elevated level of LHP (Figure 5), which could result in increased free radical activity. GPx activity is increased possibly in response to the increase of LHP in an attempt to eliminate it. It shows that the L. squarrosulus caused GPx to increase in the liver. Kuppusamy et $\mathrm{a}^{20}$ have showed that GPx activity in human peripheral blood mononuclear cells may be elevated in response to increased availability of $\mathrm{H}_{2} \mathrm{O}_{2}$. The increase in LHP could be due to inevitable stress that occurs when confined. According to Acharya et al, ${ }^{21}$ Macrocybe gigantea basidiocarp extract showed significant increase of GSH, superoxide dismutase, and CAT level in liver and conferred protection against hepatotoxicity induced by $\mathrm{CCl}_{4}$ in mice. The possible mechanism may be due to its antioxidant property and ability to scavenge free radicals, which can be correlated to the presence of flavonoid and phenolic compounds.

In humans, $\mathrm{XO}$, a superoxide producing enzyme, is normally found in the liver and not free in the blood. During severe liver damage, XO is released into the blood. This assay was carried out to assess if $L$. squarrosulus mycelial extract can cause harmful effects to the liver after 28 days of treatment. The enzyme XO catalyzes the oxidation of hypoxanthine to xanthine and then to uric acid. ${ }^{22}$ The suppression of XO in serum and liver implies a reduction in superoxide radical generation. In the presence of liver damage, $\mathrm{XO}$ is released into the serum. ${ }^{23}$ Figure 3 shows that after treatment for 28 days with high dose of extract, $\mathrm{XO}$ activity was significantly decreased compared to the control group in both serum and liver. However, in the control group and the group treated with low dose of extract, the XO level was significantly increased. This response might be due to stress that occurs when confined. After 28 days of treatment, we observed that the extract of $L$. squarrosulus did not cause any damage to the liver, as activity of enzymes such as alanine aminotransferase, aspartate aminotransferase, and alkaline phosphatase did not show significant difference between the treated and control groups (data not shown). Songa et $\mathrm{al}^{24}$ reported that Phellinus linteus contains potent antioxidant and that it showed a significant result on inhibition of XO activity. This finding was supported by Nguyen et $\mathrm{al}^{25}$ who showed that antioxidant activities of Phellinus pini increased with increasing concentration of the extracts and that $\mathrm{XO}$ activity of methanol extract of P. pini was as good as allopurinol, a positive control. However, further studies are needed to elucidate relationships between those activities and pharmacological efficacy of mushrooms.

Oxidative damage of proteins was one of the modifications leading to severe failure of biological functions and cell death. Prolonged exposure of protein to reactive molecules leads to spontaneous postsynthetic modifications, such as oxidation to form AOPPs. ${ }^{14}$ The levels of AOPP in the rats of control group and the rats treated with $L$. squarrosulus at 0 and 28 days are depicted in Figure 4. This study showed no significant difference in oxidative damage of protein between normal rats and the rats treated with the $L$. squarrosulus extract at day 0 . However, the animals treated with high-dose extract showed nonsignificant reduction in AOPP level compared to the control group after a period of 28 days. The AOPP level in the control group was higher after 28 days compared to day 0 . This might be due to confinement-induced stress. Cakatay et $\mathrm{al}^{26}$ also showed that AOPP levels in the elderly rats were significantly increased compared to the adult rats. 
LHPs are lipid peroxidation products formed due to lipid damage. According to Lakshmi et $\mathrm{al}^{27}$ the protective effect of Ganoderma lucidum, Pleurotus florida, P. sajor-caju, and $P$. rimosus extracts significantly inhibited the formation of LHP and thiobarbituric acid-reactive substances leading to membrane damage of organelle from consequent exposure to radiation and to certain chemicals which generate potent ROS in the form of $\cdot \mathrm{OH}$ or ROO in both rat liver and brain. Figure 5 shows that LHP levels were significantly elevated in serum of rats after treatment with low-dose L. squarrosulus extract for 28 days, compared to the control group. This might be due to the fact that lipid peroxidation and oxidative protein damage are distinct processes. This finding, supported by Cakatay et al, ${ }^{26}$ showed an absence of correlation between LHP and oxidative protein damage markers in aging rat muscle tissue due to oxidative stress. However, a higher dose of the extract was more beneficial in attenuating the formation of free LHPs as shown in this study.

\section{Conclusion}

In summary, this study clearly showed that L. squarrosulus mycelia antioxidant extract contains absorbable antioxidants that enter the circulating plasma and cause a significant acute increase in plasma antioxidant capacity. To the best of our knowledge, this is the first study to evaluate the bioavailability of $L$. squarrosulus mycelial antioxidant extract in vivo by determining the effect on biomarkers of antioxidant defense and oxidative stress. The bioavailable antioxidants can contribute to the beneficial effects of this mushroom. This study also proved that liquid fermentation makes the wild species of $L$. squarrosulus to be a source of antioxidant ingredient for functional foods and nutraceutical industries.

\section{Acknowledgments}

The authors would like to thank the Mushroom Research Centre, University of Malaya, Malaysia, for the mushroom culture studied, facilities and the research grant PS269/2008C and PS244/2009C. The authors also thank the Ministry of Science, Technology and Innovation (MOSTI), Malaysia, for the grant (no SF 12-02-03-2015) and the Ministry of Education for High Impact Research (MoE Grant UM.C/625/1/HIR/MoE/SC/02).

\section{Author contributions}

All authors contributed toward data analysis, drafting and revising the paper and agree to be accountable for all aspects of the work.

\section{Disclosure}

The authors report no conflicts of interest in this work.

\section{References}

1. Halliwell B, Gutteridge JM. Free radicals and antioxidants in the year. A historical look to the future. Ann N Y Acad Sci. 2000;899:136-147.

2. Lan W, Zhaojun Z, Zesheng Z. Characterization of antioxidant activity of extract from Flos Lonecerae. Drug Dev Ind Pharm. 2007;33(8): 841-847.

3. Ratnam DV, Ankola DD, Bhardwaj V, Sahana DK, Ravi Kumar MN Role of antioxidants in prophylaxis and therapy: a pharmaceutical perspective. J Control Release. 2006;113(3):189-207.

4. Rauma AL, Mykkänen $H$. Antioxidant status in vegetarians versus omnivores. Nutrition. 2000;16(2):111-119.

5. Carletti M, Cantiello M, Giantin M, et al. Serum antioxidant enzyme activities and oxidative stress parameters as possible biomarkers of exposure in veal calves illegally treated with dexamethasone. Toxicol In Vitro. 2007;21(2):277-283.

6. Turkoglu A, Duru ME, Mercan N, Kivrak I, Gezer K. Antioxidant and antimicrobial activities of Laetiporus sulphureus (Bull.) Murril. Food Chem. 2007;101(1):267-273.

7. Wong KH, Vikineswary S, Noorlidah A, Kuppusamy UR, Naidu M. Effects of cultivation techniques and processing on antimicrobial and antioxidant activities of Hericium erinaceus (Bull:Fr.) Pers. extracts. Food Technol Biotechnol. 2009;47(1):47-55.

8. Kho YS, Vikineswary S, Noorlidah A, Kuppusamy UR, Oh HI. Antioxidant capacity of fresh and processed fruit bodies and mycelium of Auricularia auricula-judae (Fr.) Quel. J Med Food. 2009;12(1): $167-174$.

9. Wong JY, Chye FY. Antioxidant properties of selected tropical wild edible mushrooms. J Food Comp Anal. 2009;22(4):269-277.

10. Mau JL, Chang CN, Huang SJ, Chen CC. Antioxidant properties of methanolic extracts from Grifola frondosa, Morchella esculenta and Termitomyces albuminosus mycelia. Food Chem. 2004;87(1):111-118.

11. Mhd Omar NA, Abdullah N, Kuppusamy UR, Abdulla MA, Sabaratnam V. Nutritional composition, antioxidant capacity and antiulcer potential of Lentinus squarrosulus (Mont.) Mycelia extract. Evid Based Complement Alternat Med. 2011;2011:8p. Available from: http://dx.doi. org/10.1155/2011/539356. Accessed January 1, 2013.

12. Apak R, Güçlü K, Özyürek M, Çelik SE. Mechanism of antioxidant capacity assays and the CUPRAC (cupric ion reducing antioxidant capacity) assay. Microchim Acta. 2008;160(4):413-419.

13. Singh NM, Bogavac L, Kalimanovska V, Jelic Z, Spasic S. Spectrophotometric assay of xanthine oxidase with $2,2^{\prime}$-azino-di (3-ethylbenzthiazoline-6-sulphonate) (ABTS) as chromogen. Clin Chim Acta. 1987;162(1):29-36.

14. Witko-Sarsat V, Friedlander M, Capeillere-Blandin C, et al. Advanced oxidation protein products as a novel marker of oxidative stress in uremia. Kidney Int. 1996;49(5):1304-1313.

15. Esterbauer H, Cheeseman KH. Determination of aldehydic lipid peroxidation products: malonaldehyde and 4-hydroxynonenal. Methods Enzymol. 1990;186:407-421.

16. Porkkala-Sarataho E, Salonen TJ, Nyyssönen K, et al. Long-term effects of vitamin $\mathrm{E}$, vitamin $\mathrm{C}$ and combined supplementation on urinary 7-hydro-8-oxo-2-deoxyguanosine, serum cholesterol oxidation products, and oxidation resistance of lipids in nondepleted men. Arterioscler Thromb Vasc Biol. 2000;20(9):2087-2093.

17. Hatano T, Edamatsu R, Mori A, Fujita Y, Yasuhara E. Effects of interaction of tannins with co-existing substances. VI. Effects of tannins and related polyphenols on superoxide anion radicals and on DPPH radical. Chem Pharm Bull. 1989;37:2016-2021.

18. Duh PD, Tu YY, Yen GC. Antioxidant activity of water extract of harn jyur (Chyrsanthemum morifolium Ramat). LWT-Food Sci Technol. 1999;32(5):269-277.

19. Hopkins J, Tudhope GR. Glutathione peroxidase in human red cells in health and disease. Br J Heamatol. 1973;25(5):563-575. 
20. Kuppusamy UR, Chong YL, Mahmood AA, Indran M, Abdullah N, Vikineswary S. Lentinula edodes (shiitake) mushroom extract protects against hydrogen peroxide induced cytotoxicity in peripheral blood mononuclear cells. Indian J Biochem Biophys. 2009;46(2):161-165.

21. Acharya K, Chatterjee S, Biswas G, Chatterjee A, Saha GK. Hepatoprotective effect of wild edible mushroom on carbon tetrachlorideinduced hepatotoxicity in mice. Int J Pharm Pharm Sci. 2012;4(3): 285-288.

22. Kong LD, Cai Y, Huang WW, Cheng CH, Tan RX. Inhibition of xanthine oxidase by some Chinese medicinal plants used to treat gout. J Ethnopharmacol. 2000;73(1-2):199-207.

23. Mccarthy RD, Long CA. Bovine milk intake and xanthine oxidase activity in blood serum. J Dairy Sci. 1976;59(6):1059-1062.

24. Songa YS, Kimb SH, Sac JH, Jina C, Limd CJ, Park EH. Anti-angiogenic, antioxidant and xanthine oxidase inhibition activities of the mushroom Phellinus linteus. J Ethnopharmacol. 2003;88(1):113-116.
25. Nguyen TK, Shin DB, Lee KR, Shin PG, Cheong JC, Yoo YB. Antiinflammatory, anti-xanthine oxidase and anti-oxidant activities of fruiting body of Phellinus pini. Paper presented at: The Korean Society of Mushroom Sciences 2013 Congress, November 2013, Cheonnam, Korea.

26. Cakatay U, Telci A, Kayali R, Tekeli F, Akcay T, Sivas A. Relation of aging with oxidative protein damage parameters in the rat skeletal muscle. Clin Biochem. 2003;36(1):51-55.

27. Lakshmi B, Tilak JC, Adhikari S, Devasagayam TP, Janardhanan KK. Inhibition of lipid peroxidation induced by g-radiation and AAPH in rat liver and brain mitochondria by mushrooms. Curr Sci. 2005;88(3):484-488.

\section{Publish your work in this journal}

Drug Design, Development and Therapy is an international, peerreviewed open-access journal that spans the spectrum of drug design and development through to clinical applications. Clinical outcomes, patient safety, and programs for the development and effective, safe, and sustained use of medicines are a feature of the journal, which has also been accepted for indexing on PubMed Central. The manuscript management system is completely online and includes a very quick and fair peer-review system, which is all easy to use. Visit http://www.dovepress.com/testimonials.php to read real quotes from published authors.

Submit your manuscript here: http://www.dovepress.com/drug-design-development-and-therapy-journal 